American Journal of Environmental Sciences 7 (4): 348-353, 2011

ISSN 1553-345X

(C) 2011 Science Publications

\title{
Microbial Activities as Affected by Peat Dryness and Ameliorant
}

\author{
Edi Husen and Fahmuddin Agus \\ Indonesian Soil Research Institute, \\ Jl. Juanda 98, Bogor, Indonesia
}

\begin{abstract}
Problem statement: Acceleration of microbial activities and thus of $\mathrm{CO}_{2}$ emission in drained peat soils used for agriculture, is of the main environmental concern. The objectives of this study were to (i) examine microbial activities in peat samples treated with different levels of water contents and ameliorants and (ii) evaluate the relative contribution of microbial groups to peat respiration. Approach: Surface $(0-20 \mathrm{~cm})$ and subsurface $(30-50 \mathrm{~cm})$ peat samples were collected from Tanjung Jabung Barat, Jambi Province, Indonesia. Peat samples were categorized as saprist (mature stage), acidic ( $\mathrm{pH}<4.5)$, low bulk density $\left(<0.12 \mathrm{~g} \mathrm{~cm}^{-3}\right)$ and high carbon content $(\mathrm{C}>500 \mathrm{~g}$ $\mathrm{kg}^{-1}$ ). Each peat sample was treated with four different levels of water contents (7-66\%, v/v) and four levels of ameliorant applications (without and with $600 \mathrm{~kg} \mathrm{ha}^{-1}$ furnace slag and/or lateritic-soil). Another set of peat samples was treated with three different lethal doses of chemical agents to inhibit the growth of selected microbial group (bacteria, actinomycetes and fungi). The rate of respiration and the number of individual microbial group population were estimated by alkali absorption method and spread-plate counting technique, respectively. Results: Application of furnace slag and/or lateritic soil at the level of $600 \mathrm{~kg} \mathrm{ha}^{-1}$ did not affect peat respiration. However, respiration rates increased as the water content of peat samples increased, namely from 4.23-18.2 $\mu \mathrm{g} \mathrm{CO}_{2} \mathrm{~g}^{-1} \mathrm{~h}^{-1}$ in the surface samples and from 6.19-15.84 $\mu \mathrm{g} \mathrm{CO}_{2} \mathrm{~g}^{-1} \mathrm{~h}^{-1}$ in the subsurface samples. Bacteria were the dominant microbial group in both samples ranging from 9.39-12.76 $\log _{10}$ cell $\mathrm{g}^{-1}$ and contributed to 82 and $58 \%$ of surface and subsurface peat respiration, respectively. Conclusion: Microbial activities, notably bacteria were affected by peat water content and less affected by ameliorants of furnace slag and lateritic soil. Increasing water content up to $66 \%$ increased peat respiration, indicating the preference of the microbes to moist condition.
\end{abstract}

Key words: Jambi province, microbial activity, peat soil, peat respiration, furnace slag, lateritic soil, ameliorant, alkali absorption

\section{INTRODUCTION}

Interest in the acceleration of microbial activities due to land use changes has been increasing in the last few years, notably in area of peat soils with high carbon source. As a key component in carbon cycle increased activities of heterotrophic microorganisms, which are commonly depicted by its respiration, results in the release of carbon dioxide $\left(\mathrm{CO}_{2}\right)$ to the atmosphere (Anderson and Ineson, 1982; Ewel et al., 1987). The higher the activities, the more intense are the $\mathrm{CO}_{2}$ produced.

High accumulation of organic matter in peat soils subjects to decomposition by soil microflora providing that various factors in the soils are conducive for their growth and development. Several factors that influence microbial activity include soil moisture, temperature (Howard and Howard, 1993; Alef and Nannipieri, 1995; Chow et al., 2006; Makiranta et al., 2009; Kechavarzi et al., 2010), nutrient and substrate availability (Smith, 2005) in combination with peat properties such $\mathrm{pH}$, cations, cation exchange capacity and clay content (Thomas and Pearce, 2003; Wang et al. 2003; Gogo and Pearce, 2009; Luka et al., 2009). In most cases, air-drying reduces soil respiration and remoistening promotes the initial activities as the results of increasing concentration of easily degradable organic compounds such as amino and organic acids.

Corresponding Author: Edi Husen, Indonesian Soil Research Institute, Jl. Juanda 98, Bogor, Indonesia

Tel/Fax: +62 2518336757 
However, a study by Hooijer et al. (2010) in peat land agriculture found that the deeper the groundwater level, the higher was the $\mathrm{CO}_{2}$ emission, which indicates that decreasing soil moisture content increases peat respiration. This implies the influence of some other factors in peat respiration. On the other hand, the complexity of organic matter molecular chain determines the ease of its degradation. Simple (monomeric) organic acids are readily biodegraded relative to the more complex ones. Addition of ameliorants that contain high valence cations may form a ligand complex with the simple organic acids and thus reducing the rate of peat decomposition. Acid soil clay containing high amount of $\mathrm{Al}^{3+}$ and $\mathrm{Fe}^{3+}$ is a good candidate as a peat soil ameliorant. Furnace slag with high contents of $\mathrm{Zn}^{2+}, \mathrm{Cu}^{2+}$ and $\mathrm{Fe}^{3+}$ may also give some effects in reducing microbial respiration.

This study examined the rates of microbial activities in peat soil treated with different levels of water contents and ameliorants and the relative importance of the individual microbial group (bacteria, actinomycetes and/or fungi) in peat respiration.

\section{MATERIALS AND METHODS}

Peat sampling and properties: Peat samples were collected from 8 year-old oil palm plantation in Tanjung Jabung Barat, Jambi Province, Indonesia $\left(1^{\circ}\right.$ 01' 46.3" S $103^{\circ} 19^{\prime} 51.7^{\prime \prime}$ E). Two separate bulks of peat materials were collected from the surface $(0-20 \mathrm{~cm}$ depth) and subsurface $(30-50 \mathrm{~cm} \mathrm{depth})$. Prior to treatment, each bulk of peat sample was thoroughly mixed and cleaned from root debris and analyzed for physical and chemical characteristics in the Soil Physic and Chemistry Laboratory of Indonesian Soil Research Institute (ISRI), Bogor.

Peats were at the mature stage (saprist properties), acidic ( $\mathrm{pH}<4.5)$, low Bulk Density (BD), high carbon content $\left(\mathrm{C}>500 \mathrm{~g} \mathrm{~kg}^{-1}\right)$, high Cation Exchange Capacity (CEC) and low Base Saturation (BS). In general, peat at surface layer was more compacted, more mature and fertile than at subsurface layer (Table 1).
Ameliorant and water content adjustment (Experiment-1): Two kinds of ameliorants, i.e., Furnace Slag (FS) containing $\mathrm{CuSO}_{4} \cdot 5 \mathrm{H}_{2} \mathrm{O}+\mathrm{ZnSO}_{4}$ and lateritic (clayey) soil (Lt) were prepared and homogenized using 250-mesh sieve. Prior to application, water content of peat sample was measured gravimetrically after drying at $105^{\circ} \mathrm{C}$ for $24 \mathrm{~h}$. Each ameliorant was mixed thoroughly with the sample at the dose of $600 \mathrm{~kg} \mathrm{ha}^{-1}$ and incubated for 10 days at room temperature $\left( \pm 28^{\circ} \mathrm{C}\right)$. Four levels of ameliorant application, i.e., zero (without ameliorant), FS, Lt and FS+Lt were assigned as the first factor of the treatments. After 10-day incubation, the sample at the same level of ameliorant was divided into 4 sub-samples for 4 levels of different water contents, which were assigned as the second factor of the treatments. Water contents of each sub-sample were adjusted by re-wetting with sterile distilled water and air-drying for 3-9 days at open air conditions and expressed as percent volume (by multiplying the dry weight of the sample with BD). The initial water contents of surface and subsurface samples ranged from $31.6-36.6 \%$.

The rate of respiration and the number of microbial group population from each combined treatment (16 treatments) were determined on the basis of dry weight. Except for microbial population that was counted in duplicate, the respiration was measured in four replications. Data were analyzed by analysis of variance (ANOVA) and treatment means were separated by the Least Significance Difference (LSD; $\mathrm{p}=0.05$ ) using the SAS systems for Windows v6.12.

Induction and inhibition of selective microbial groups (Experiment-2): The assay was based on the stimulation of the overall active microbial population in the sample by adding a readily degradable substrate and simultaneously inhibition of a selective microbial group by adding specific inhibitors (Alef and Nannipieri, 1995). Under no differentiation of water content, the importance of the individual groups of bacteria, fungi and actinomycetes in peat respiration was evaluated by selective inhibition technique using selective chemical agents and in combination with the application of glucose to induce the respiration.

Table 1: Some characteristics of peat samples collected from oil palm plantation in Tanjung Jabung Barat, Jambi Province, Indonesia

\begin{tabular}{|c|c|c|c|c|c|c|c|c|c|c|c|c|}
\hline \multirow[b]{2}{*}{$\begin{array}{l}\text { Depth } \\
(\mathrm{cm})\end{array}$} & \multirow[b]{2}{*}{ Maturity } & \multirow[b]{2}{*}{$\begin{array}{l}\mathrm{BD} \\
\mathrm{g} \mathrm{cm}^{-3}\end{array}$} & \multirow[b]{2}{*}{$\begin{array}{l}\mathrm{pH} \\
\left(\mathrm{H}_{2} \mathrm{O}\right)\end{array}$} & \multirow[b]{2}{*}{$\begin{array}{l}\mathrm{C} \\
\text { (LOI) }\end{array}$} & \multirow[b]{2}{*}{$\begin{array}{l}\mathrm{N} \\
(\text { Kjeldahl }) \\
\mathrm{kg}^{-1} \ldots \ldots \ldots . . .\end{array}$} & \multirow[b]{2}{*}{$\mathrm{C} / \mathrm{N}$} & $\mathrm{P}_{2} \mathrm{O}_{5}$ & $\mathrm{~K}_{2} \mathrm{O}$ & \multirow[b]{2}{*}{$\begin{array}{l}\mathrm{P}_{2} \mathrm{O}_{5} \\
(\mathrm{Bray} 1) \\
\ldots \ldots \ldots \ldots . . .\end{array}$} & \multicolumn{3}{|l|}{ Cation } \\
\hline & & & & & & & $(\mathrm{HC}$ & $\mathrm{mg} \mathrm{kg}^{-1}$.. & & $\begin{array}{l}\mathrm{NH}_{4}-\mathrm{A} \\
\ldots \ldots \mathrm{cm}\end{array}$ & & $\begin{array}{l}\text { BS } \\
(\%)\end{array}$ \\
\hline $0-20$ & Saprist & 0.12 & 4.5 & 531.7 & 14.1 & 38 & 390 & 120 & 229 & 30.38 & 70.5 & 43 \\
\hline $30-50$ & Saprist & 0.07 & 3.7 & 497.9 & 10.3 & 48 & 150 & 100 & 60 & 5.88 & 76.8 & 8 \\
\hline
\end{tabular}


The chemical agents to kill or inhibit the target microorganism included antifungal cycloheximide and anti-bacteria and/or-actinomycetes rifampicin + chloramphenicol. Moist peat sample was first divided into nine sub-samples, each of which was applied with different combined treatments of lethal dose for bacteria and fungi. Three levels of Lethal Dose (LD) for bacteria (the first factor) and fungi (the second factor) were zero, 50 and $100 \%$ of LD. The LD $100 \%$ for bacteria (LDB-100\%) and fungi (LDF-100\%) were 120 $\mu \mathrm{g}$ rifampicin+600 $\mu \mathrm{g}$ chloramphenicol and $400 \mu \mathrm{g}$ cycloheximide per gram peat sample, respectively. A $2000 \mu \mathrm{g}$ glucose per gram peat sample was added to all sub-samples. The rate of respiration and the number of microbial group population (each in duplicate) were determined from each combined treatment (9 treatments). Rough estimation of bacteria and fungi respiration was counted with the following formula:

The respiration of bacteria $=\{(\mathrm{A}-\mathrm{B}) /(\mathrm{A}-\mathrm{D})\} \times 100 \%$ The respiration of fungi $=\{(\mathrm{A}-\mathrm{C}) /(\mathrm{A}-\mathrm{D})\} \times 100 \%$

where, A, B, C and D are the respiration from sample treated with (LDB-0 and LDF-0\%), (LDB-100 and LDF-0\%), (LDB-0 and LDF-100\%) and (LDB-100 and LDF-100\%), respectively.

Respiration assay: Measuring respiration of treated samples was conducted by alkali absorption method adapted from Alef and Nannipieri (1995) and Weaver and Mickelson (1994). The principle of the method is the measurement of $\mathrm{CO}_{2}$ evolved during incubation of the sample with $\mathrm{NaOH}$ solution and the $\mathrm{CO}_{2}$ trapped in $\mathrm{NaOH}$ solution is titrated with $\mathrm{HCl}$. A $50 \mathrm{~g}$ of treated sample in an aluminum can (as prepared in the experiment-1 and -2) and $25 \mathrm{~mL}$ of $0.05 \mathrm{M} \mathrm{NaOH}$ solution in a $50 \mathrm{~mL}$ beaker glass were placed inside a 2.7 L tightly sealable jar (13 cm in length, $13 \mathrm{~cm}$ in wide, 16 $\mathrm{cm}$ in height). The jars with treated samples and the jars without the sample (blank/control) were quickly covered and incubated for $24 \mathrm{~h}$. at room temperature. After $24 \mathrm{~h}$. incubation, the jar was opened and $\mathrm{NaOH}$ solution was titrated with $0.01 \mathrm{M} \mathrm{HCl}$ using an automatic titration device. During the titration, the jars were remained open to replenish $\mathrm{O}_{2}$ and incubated again for next $24 \mathrm{~h}$. period with new $\mathrm{NaOH}$ solution. Each period of incubation represented as a replication (4 replications). The rate of respiration was calculated as follow:

$$
\mathrm{CO}_{2}(\mu \mathrm{g}) / \mathrm{SWT} / \mathrm{t}=\frac{\{(\mathrm{V} 0-\mathrm{V}) \times 1.1\}}{\mathrm{dwt}}
$$

Where:

SWT $=$ The amount of sample in gram

$\mathrm{t}=$ The incubation time in hours
$\mathrm{V0}=$ The volume of $\mathrm{HCl}$ used for titration of blank/control in milliliter

$\mathrm{V}=$ The volume of $\mathrm{HCl}$ used for titration of the sample in milliliter

$\mathrm{dwt}=$ The dry weight of $1 \mathrm{~g}$ sample (after drying at $105^{\circ} \mathrm{C}$ for $24 \mathrm{~h}$ )

$1.1=$ The conversion factor $(1 \mathrm{~mL} 0.05 \mathrm{M} \mathrm{NaOH}$ equals $1.1 \mathrm{mg} \mathrm{CO}_{2}$ )

Enumeration of microbial group population: In line with soil respiration test, the individual of microbial group population, e.g. bacteria, actinomycetes and fungi, was enumerated from each treated sample (as prepared in the experiment-1 and -2). The enumeration was conducted by spread plate counting technique from dilution series of the sample (Weaver and Mickelson, 1994). The plates containing solid (agar) media for each microbial group were selected to yield the highest number of colonies. They were M26 with $10 \%$ strength, Rose Bengal Malt Extract (RBME) and Potato Dextrose Agar (PDA) for bacteria, actinomycetes and fungi, respectively. The composition of each medium in 1000 $\mathrm{mL}$ distilled water was $1 \mathrm{~g}$ beef extract, $1 \mathrm{~g}$ peptone, $5 \mathrm{~g}$ $\mathrm{NaCl}, 15 \mathrm{~g}$ agar for M26 medium; $10 \mathrm{~g}$ malt extract, 0.5 $\mathrm{g} \mathrm{KH}_{2} \mathrm{PO}_{4}, 0.067 \mathrm{~g}$ rose bengal, $17 \mathrm{~g}$ agar and $50 \mu \mathrm{g}$ $\mathrm{mL}^{-1}$ anti fungal cycloheximide for RBME medium; 20 $\mathrm{g}$ potato dextrose agar supplemented with $100 \mu \mathrm{g} \mathrm{mL}^{-1}$ antibacterial rifampicin for PDA medium. All constituents of each media were mixed and sterilized by autoclaving at $121^{\circ} \mathrm{C}$ for $15 \mathrm{~min}$.

\section{RESULTS AND DISCUSSION}

Effects of water content and ameliorants: There was no interaction effects between water content (SWC) and ameliorant application on the respiration rates of treated samples. The effect of each treatment was independent. The rate of respiration of treated samples ranged from 4.23-18.20 $\mu \mathrm{g} \mathrm{CO}_{2} \mathrm{~g}^{-1} \mathrm{~h}^{-1}$ (surface peat with 7-66\% SWC) and 6.19-15.84 $\mu \mathrm{g} \mathrm{CO}_{2} \mathrm{~g}^{-1} \mathrm{~h}^{-1}$ (subsurface peat with 16-60\% SWC). Except at SWC $<16 \%$, the rates of respiration increased significantly as the SWC increase indicating that the higher the SWC is the better the respiration (Fig. 1). Although it was not measured in this study, further increase of SWC for long time period could lower the respiration rates as the water creates anaerobic conditions. A study by Chow et al. (2006) reported that wet-dry cycles enhanced the penetration of oxygen and promoted the degradation of raw peat materials, but prolong incubation (long-term anaerobic conditions) lowered peat degradation.

Applying ameliorants at $600 \mathrm{~kg} \mathrm{ha}^{-1} \mathrm{did}$ not affect the respiration rates; rather it biased to 
accelerate the respiration, especially at samples treated with Furnace Slag (FS). However, the effects of lateritic soil varied across water content and peat materials (surface and subsurface samples). At $>60 \%$ SWC, application of lateritic soil (clay) to subsurface samples inclined to reduce respiration rates indicating that at high dose application its effect could be significant. A study by Wang et al. (2003) indicated that the protective effect of clay on soil organic matter decomposition became significant as the supply of substrate and microbial demand approached to an equilibrium state. Further explore on the potential use of lateritic soil to protect peat decomposition is required.
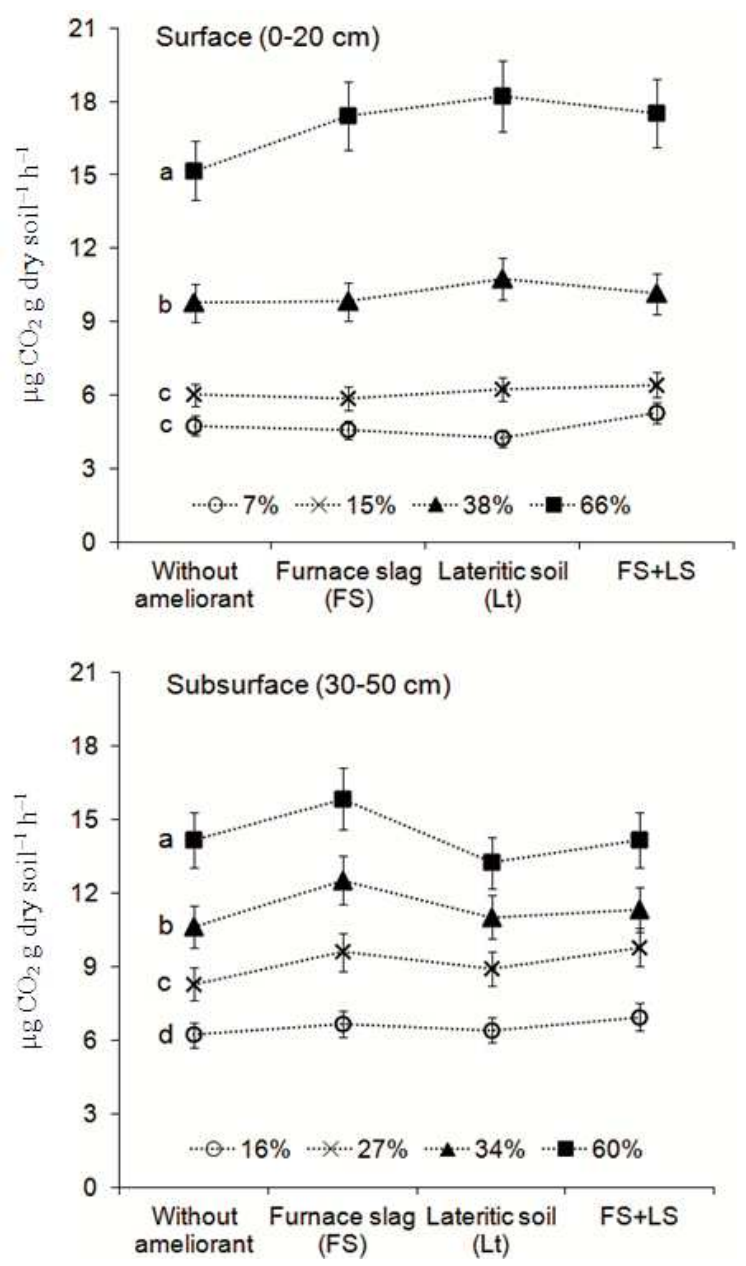

Fig.1: Effects of water content (\%, v/v) and ameliorants (furnace slag and lateritic soil) on respiration rates. Means of the respiration values in each level of ameliorant followed by the same letter are not significantly different at 5\% level by LSD (LSD of surface sample $=2.15$ and subsurface sample $=1.88$ )
Bacterial was the dominant groups of microbial population in both surface and subsurface samples, which ranged from 9.39-12.76 $\log 10$ cell $\mathrm{g}^{-1}$, followed by fungi and actinomycetes which ranged from 4.846.91 and 3.46-6.80 $\log 10$ cell g $^{-1}$, respectively (Fig. 2). Bacterial population increased as the SWC samples increased. This trend was followed only by fungi and actinomycetes population in the subsurface peat samples indicating that some peat properties may influence their growth and development, such as cation availability and CEC as suggested by Thomas and Pearce (2003).
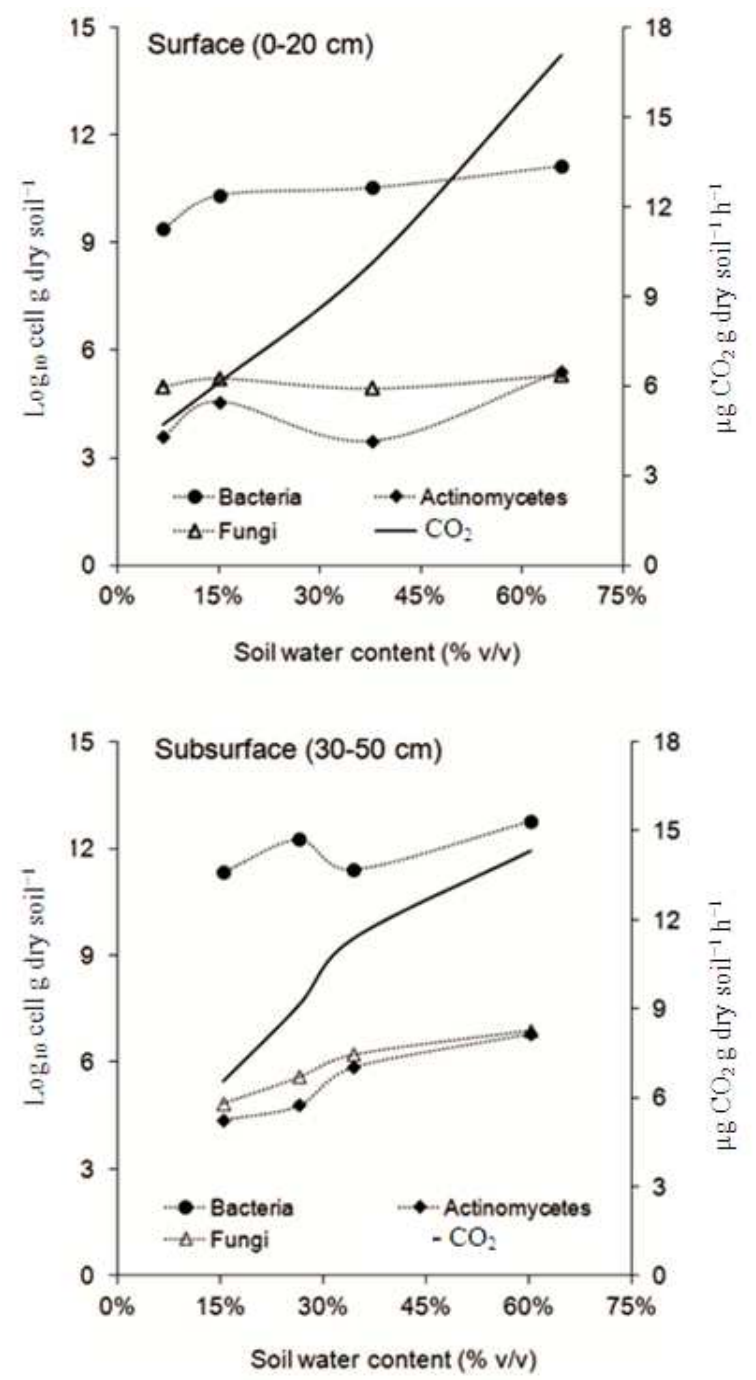

Fig.2: Individual microbial group population (bacteria, actinomycetes and fungi) in surface and subsurface samples treated with different water content and its relation to respiration rates 
Am. J. Environ. Sci., 7 (4): 348-353, 2011

Table 2: Data correlation amongst respiration $\left(\mu \mathrm{g} \mathrm{CO}_{2} \mathrm{~g}^{-1} \mathrm{~h}^{-1}\right)$, water content $(\%, \mathrm{v} / \mathrm{v})$ and microbial group population parameters $\left(\log _{10}\right.$ cell $\left.\mathrm{g}^{-1}\right)$ of surface and subsurface peat samples

\begin{tabular}{|c|c|c|c|c|c|}
\hline Parameters & Respiration & Water content & Bacteria & Actinomycetes & Fungi \\
\hline \multicolumn{6}{|l|}{ Surface peat $(0-20 \mathrm{~cm})$} \\
\hline Respiration & 1.0000 & & & & \\
\hline Water content (SWC) & 0.9958 & 1.0000 & & & \\
\hline Bacteria & 0.8938 & 0.9108 & 1.0000 & & \\
\hline Actinomycetes & 0.6825 & 06332 & 0.6993 & 1.0000 & \\
\hline Fungi & 0.5458 & 0.4930 & 0.6076 & 0.9842 & 1.0000 \\
\hline \multicolumn{6}{|c|}{ Subsurface peat $(30-50 \mathrm{~cm})$} \\
\hline Respiration & 1.0000 & & & & \\
\hline Water content (SWC) & 09760 & 1.0000 & & & \\
\hline Bacteria & 0.6792 & 0.7675 & 1.0000 & & \\
\hline Actinomycetes & 0.9847 & 0.9687 & 0.5908 & 1.0000 & \\
\hline Fungi & 0.9985 & 0.9628 & 0.6578 & 0.9796 & 1.0000 \\
\hline
\end{tabular}
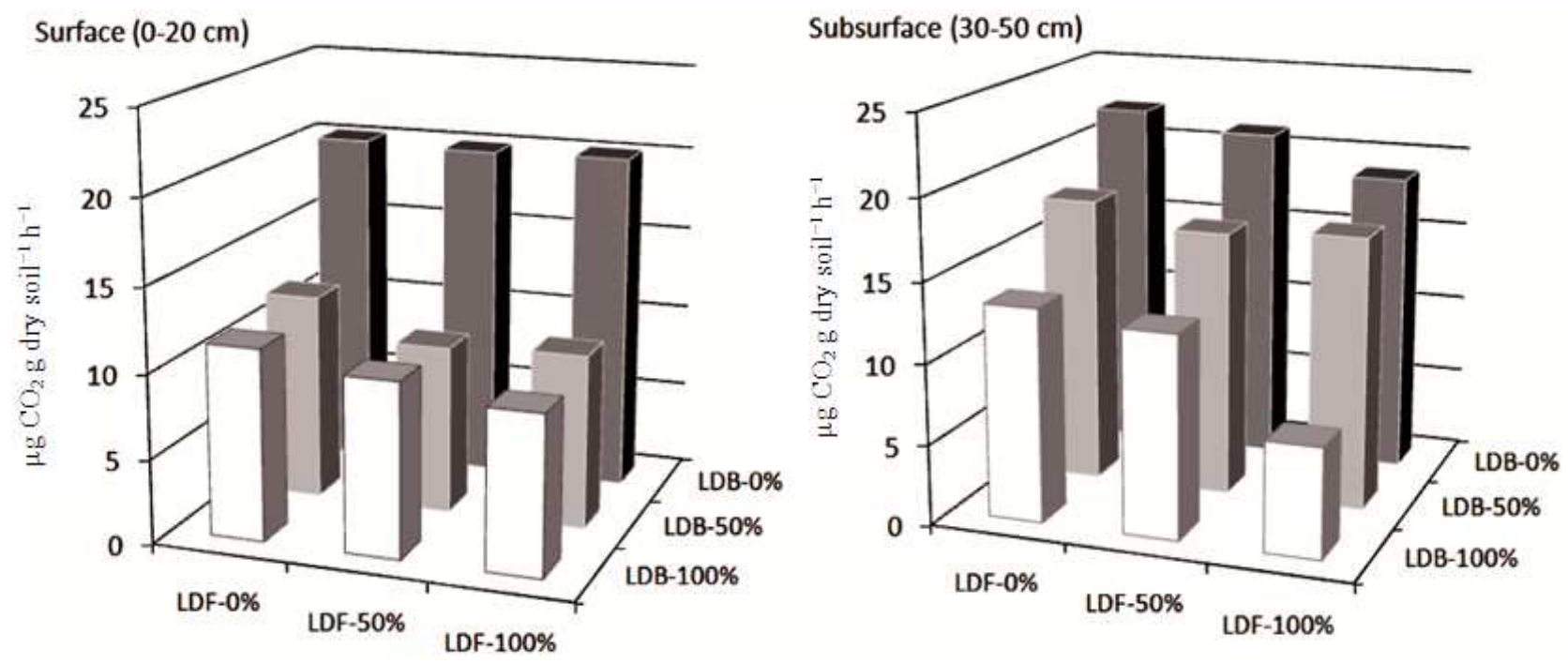

Fig.3: Respiration rates of peat samples treated with 3 levels of lethal dose of chemical agents for bacteria (LDB) and for fungi (LDF)

High population of bacteria and their relative high correlation with SWC $\left(\mathrm{R}^{2}=0.91\right)$ and respiration $\left(\mathrm{R}^{2}=\right.$ 0.89) indicates that bacteria could be the most responsible microbes in peat respiration, especially in surface peat sample (Table 2).

Contribution of individual microbial group in peat respiration: Killing or inhibiting the growth of bacteria by lethal dose of chemical agents reduced sharply the respiration rates of both surface and subsurface peat samples. Similar action of fungi was not influenced much on the respiration rates (Fig. 3). This result confirmed the previous data showing the high population of bacteria and their contribution to the respiration rate of peat samples. By using the equation, respiration of bacteria in surface and subsurface peat samples was about 82 and $58 \%$, respectively.

\section{CONCLUSION}

Microbial activities in peat soils were affected by water content, but less affected by ameliorants. Increasing peat water content up to $66 \%(\mathrm{v} / \mathrm{v})$ increased microbial population and respiration, but application of furnace slag and lateritic soil (clay) at the level of 600 $\mathrm{kg}$ ha-1 was not significant to reduce peat respiration. Soil bacteria were the dominant group of microbial population in peat sample and the most responsible in peat respiration (decomposition). This implies that over-draining of peat reduces emission, but moistening by rain water and water management system increases emission. The thickness of the unsaturated moist layer seems to affect emission the most. Critical water content and depth of drainage are worth for further investigation under field condition. 
Am. J. Environ. Sci., 7 (4): 348-353, 2011

\section{ACKNOWLEDGEMENT}

The research leading to these results has received funding from the European Community's Seventh Framework Programme [FP7/2007-2013] under grant agreement No. 226310.

\section{REFERENCES}

Alef, K. and P. Nannipieri, 1995. Methods in Applied Soil Microbiology and Biochemistry. 1st Edn., Academic Press, London, pp: 576.

Anderson, J.M. and P. Ineson, 1982. A soil microcosm system and its application to measurements of respiration and nutrient leaching. Soil Biol. Biochem., 14: 415-416.

Chow, A.T., K.K. Tanji, S. Gao, and R.A. Dahlgren, 2006. Temperature, water content and wet-dry cycle effects on DOC production and carbon mineralization in agricultural peat soils. Soil Biol. Biochem., 38: 477-488. DOI: 10.1016/j.soilbio.2005.06.005

Ewel, K.C., W.P. Cropper Jr. and H.L. Gholz, 1987. Soil $\mathrm{CO}_{2}$ evolution in Florida slash pine plantations. II. Importance of root respiration. Can. J. For. Res., 17: 330-333. DOI: 10.1139/x87-055

Gogo, S. and D.M.E. Pearce, 2009. Carbon, cations and CEC: Interactions and effects on microbial activity in peat. Geoderma, 153: 76-86. DOI: 10.1016/j.geoderma.2009.07.015

Hooijer, A., S. Page, J.G. Canadell, M. Silvius and J. Kwadijk et al., 2010. Current and future $\mathrm{CO}_{2}$ emissions from drained peatlands in Southeast Asia. Biogeosciences, 7: 1505-1514. DOI: 10.5194/bg-7-1505-2010

Howard, D.M. and P.J.A. Howard, 1993. Relationships between $\mathrm{CO}_{2}$ evolution, moisture content and temperature for a range of soil types. Soil Biol. Biochem., 25: 1537-1546. DOI: 10.1016/00380717(93)90008-Y
Kechavarzi, C., Q. Dawson, M. Bartlett and P.B. LeedsHarrison, 2010. The role of soil moisture, temperature and nutrient amendment on $\mathrm{CO}_{2}$ efflux from agricultural peat soil microcosms. Geoderma, 154: 203-210. DOI: 10.1016/j.geoderma.2009.02.018

Luka, A., B. Kraigher and I. Mandic-Mulec, 2009. Differences in the activity and bacterial community structure of drained grassland and forest peat soils. Soil Biol. Biochem., 41: 1874-1881. DOI: 10.1016/j.soilbio.2009.06.010

Makiranta, P., R. Laiho, H. Fritze, J. Hytonen, J. Laine and K. Minkkinen, 2009. Indirect regulation of heterotrophic peat soil respiration by water level via microbial community structure and temperature sensitivity. Soil Biol. Biochem., 41: 695-703. DOI: 10.1016/j.soilbio.2009.01.004

Smith, V.R., 2005. Moisture, carbon and inorganic nutrient controls of soil respiration at a subAntarctic island. Soil Biol. Biochem., 37: 81-91. DOI: 10.1016/j.soilbio.2004.07.026

Thomas, P.A. and D.M.E. Pearce, 2003. Role of cation exchange in preventing the decay of anoxic deep bog peat. Soil Biol. Biochem., 36: 23-32. DOI: 10.1016/j.soilbio.2003.07.003

Wang, W.J., R.C. Dalal, P.W. Moody and C.J. Smith, 2003. Relationships of soil respiration to microbial biomass, substrate availability and clay content. Soil Biol. Biochem., 35: 273-284. DOI: 10.1016/S0038-0717(02)00274-2

Weaver, R.W. and S.H. Mickelson, 1994. Methods of Soil Analysis: Microbiological and Biochemical Properties. 3rd Edn., Soil Science Society of America, Madison, Wis., ISBN: 0-89118-810-X, pp: 1121 . 